\title{
BOEKBESPREKING: EEN REQUIEM VOOR EEN MUSEUM Nusantara - Highlights from the Museum Nusantara Delft
}

Overvalt u ook een weemoedig gevoel als u met de trein door Delft en langs het oude pand van Museum Nusantara rijdt? Het museum is al enige tijd gesloten, maar wat is het lot van de collecties die eigendom zijn van de gemeente Delft? Het deel van de collectie dat betrekking heeft op de geschiedenis van Delft en de Indische Instelling zal in Delft blijven, een aantal objecten is opgenomen in het vernieuwde Prinsenhof en het 'restant' wordt na zorgvuldig onderzoek herplaatst. ${ }^{1}$

Het bestuur van de Stichting Nusantara heeft na de sluiting van het museum besloten om de hoogtepunten uit de collectie te presenteren in een publicatie: "Zo zal het Museum Nusantara toch een beetje blijven bestaan, ook al zal de collectie in een andere museale context worden ondergebracht." Met dit boek dat 150 jaar na de oprichting van de Indische Instelling is gepubliceerd, heeft de Stichting Nusantara voor een waardige afsluiting zorg gedragen.

Het boek begint met een inleiding waarin de geschiedenis van de Indische Instelling, de verzamelgeschiedenis en de belangrijke personen gedurende 150 jaar wordt beschreven. Het is fascinerend om te lezen hoe de collecties en de presentaties sinds de opheffing van de Indische Instelling in 1901 altijd onder vuur hebben gelegen. Het zet de lezer aan het denken over hoe er nu over collecties wordt gedacht én hoe bepaalde personen met grote bevlogenheid de verzamelingen iedere keer weer wisten te redden van de ondergang. Onbedoeld geeft de inleiding met deze heldere en bondige beschrijving een beeld van de situatie waarin kleinere musea in Nederland vaak verkeren: de gedrevenheid van de betrokkenen om ondanks de beperkte beschikbaarheid van middelen mooie tentoonstellingen te maken voor het publiek. Wie in Nusantara is geweest, zal zich de muur met affiches van exposities misschien nog herinneren: een rijkdom aan thema's en onderwerpen.

De laatste periode van het museum wordt kort en diplomatiek aangestipt, maar de beweegreden van de gemeente Delft wordt nog even aangehaald: het museum trok te weinig bezoekers. Ook hier wordt een ontwikkeling in de Nederlandse museale sector blootgelegd. Het belang en/of kwaliteit van collecties vormt geen basis voor het bestaansrecht, en is vervangen door bezoekcijfers. De auteur laat zich wijselijk niet uit over deze verandering van grondhouding.

Tot zover boeit de inleiding, maar de laatste paragraaf roept toch ook vragen op. Bijzonder is dat de auteur kritisch is over de collectie. Hij geeft aan dat de kwaliteit niet altijd consistent is. De collectie krijgt terecht het label "divers met een unieke historie", maar de conclusie dat niet alle eilanden en regio's even goed worden vertegenwoordigd en dat textiel wel een heel groot deel beslaat, wordt niet uit de weg gegaan. De auteur had kunnen kiezen om deze bevinding te verzwijgen om afbreuk aan de collectie te voorkomen. Door de access 


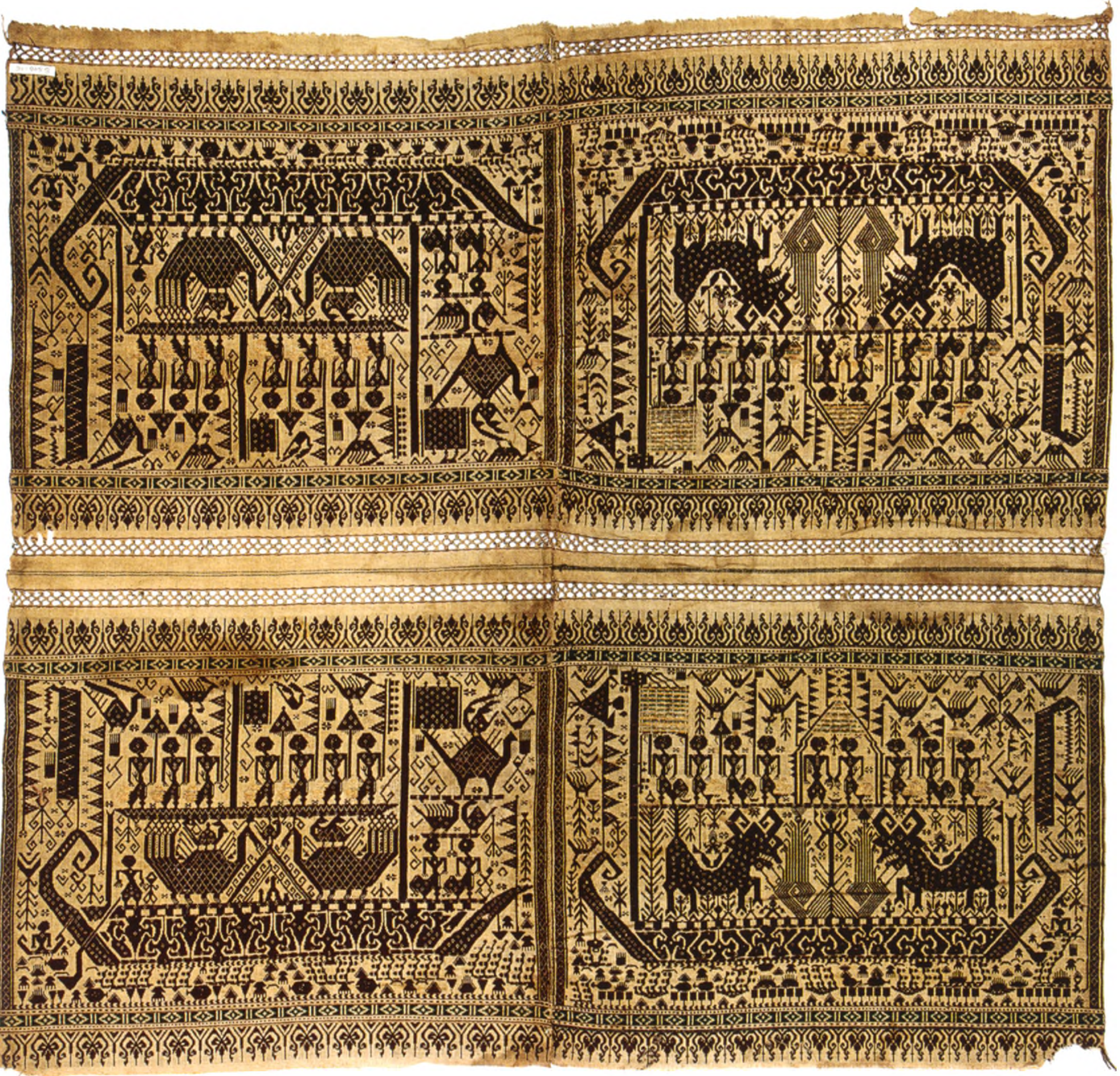

Afb. 1

Tampan, Indonesië, Zuid-Sumatra, Lampung, $19^{e}$ eeuw, Museum Nusantara, inv.nr. S 546-120. samenstelling van de collectie direct te verbinden aan de verzamelgeschiedenis heeft hij dit weten te voorkomen.

In de paragraaf wordt een verantwoording gegeven over de keuzes die gemaakt zijn. Er wordt kortweg aangegeven dat de selectie het resultaat is van keuzes, maar helaas wordt de achtergrond van die keuzes, en vooral wie betrokken waren bij die keuzes, niet toegelicht. Juist bij een diverse collectie als die van Museum Nusantara zou een nadere toelichting op de selectie waardevol geweest zijn. Een korte beschrijving van objectgroepen (met eventueel aantallen) zou ook een nuttige aanvulling zijn geweest.

De selectie bevat verder enkel objecten die in Indonesië voor de eigen lokale samenleving zijn gemaakt. Objecten uit de VOC-periode en de koloniale periode ontbreken. Omdat een beschrijving van objectgroepen en een toelichting op de keuzes ontbreekt, is het onduidelijk of er meer collectie-

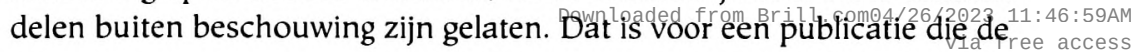




\section{8}

Afb. 2

Yene (voorouderfiguur), Indonesië, zuidwestelijke Molukken, Leti-eilanden, Museum Nusantara, inv.nr. S 527-35.

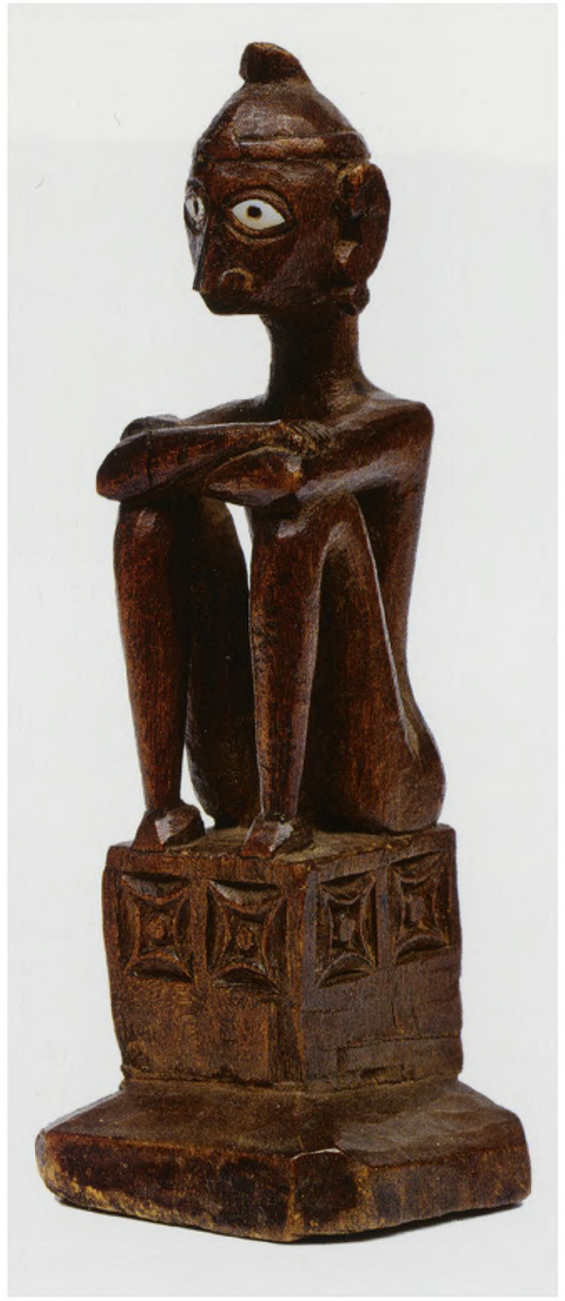

afsluiting vormt van het museum een groot gemis. Een mooie aanvulling vormen de biografieën van personen die belangrijk zijn geweest voor het museum.

In het catalogusgedeelte worden de objecten gegroepeerd aan de hand van de eilanden van herkomst. De selectie maakt heel duidelijk hoe divers de cultuuruitingen binnen de Indonesische archipel zijn. Deze diversiteit is vermoedelijk ook de oorzaak van de helaas niet altijd evenwichtige objectteksten. Om alle objecten van een goede inhoudelijke tekst te kunnen voorzien is een waaier aan kennis nodig. De auteur heeft van een aantal mensen ondersteuning gekregen en hij heeft dankbaar gebruik gemaakt van de beschikbare literatuur over de collectie. Dat neemt niet weg dat sommige objecten alleen een droge beschrijving hebben gekregen en andere objecten gloedvol en veel uitgebreider worden behandeld waarbij ook context wordt gegeven. Een groot pluspunt van sommige teksten is dat zij het oog van de lezer langs het object begeleiden. De tekst ondersteunt dan de afbeelding en zorgt ervoor dat de lezer meer details ziet én begrijpt. Wat sommige teksten aantrekkelijk maakt, is dat de herkomstgeschiedenis, voor zover natuurlijk bekend, opgenomen is. 
Datering van voorwerpen is niet altijd even gemakkelijk en dat geldt ook voor een deel van de collectie van Museum Nusantara. Het boek kent geen toelichting op de objectinformatie als materiaal, lengte, datering etc. Soms wordt een datering gegeven, soms in het geheel niet. In andere gevallen ontbreekt de datering, maar wordt het jaar van verwerving (en van wie het verworven is) benoemd. In andere gevallen wordt de datering wel genoemd in de objecttekst. Deze inconsequentie ten aanzien van dateringen is een schoonheidsfout die bij de lezer soms vertwijfeling oproept. Zijn de schilden uit Kalimantan uit de $19^{\mathrm{c}}$ of $20^{\mathrm{e}}$ eeuw? Het jaar van verwerving, 1991, geeft geen uitsluitsel.

De vormgeving is rustig, en tekst en afbeeldingen hebben veel ruimte gekregen. Storend zijn de afbeeldingen die over twee pagina's lopen. Bij een repeterend motief op textiel is dat niet erg, maar bij een rencong met verfijnde details doet het afbreuk aan het object. Daarnaast zouden zeker bij (verfijnd) textiel uitvergrotingen welkom zijn geweest. De afbeeldingen zelf zijn helder en goed uitgelicht. "Dramatische" belichting kan heel mooi zijn, maar bij een collectieboek is niets zo irritant als een object dat maar half zichtbaar is. De betrokkenen hebben er gelukkig voor gekozen om de voorwerpen duidelijk af te beelden.

Ondanks de bovenstaande kanttekeningen is Nusantara - Highlights from the Museum Nusantara Delft een publicatie die de rijkdom en diversiteit van de verzamelingen presenteert. Het initiatief van de Stichting Nusantara heeft ervoor gezorgd dat de verzamelgeschiedenis en de personen die een belangrijke rol hebben gespeeld niet snel in het vergeetboek zullen raken. Het boek vormt daarom een waardig afscheid van Museum Nusantara, al hadden liefhebbers van Indonesische kunst en etnografica waarschijnlijk liever nog een bezoek gebracht aan het oude museum.

- Rebecca Roskam studeerde Talen en Culturen van Zuidoost Azië en Oceanië aan de Universiteit Leiden. Sinds 2001 is zij werkzaam in de Nederlandse museumwereld en vanaf 2009 is zij bestuurslid van de Vereniging van Vrienden der Aziatische Kunst.

- Nusantara - Highlights from the Museum Nusantara Delft

Arnold Wentholt, 2014. Published by C. Zwartenkot Art Books, Leiden in association with Stichting Nusantara. ISBN/EAN: 978-90-5450-013-1

\section{noot}

1. http://www.mondriaanfonds.nV/Gehonoreerd/item/2014_07_30_Nusantara_Collectie/ (laatst bekeken 16-9-2014). 


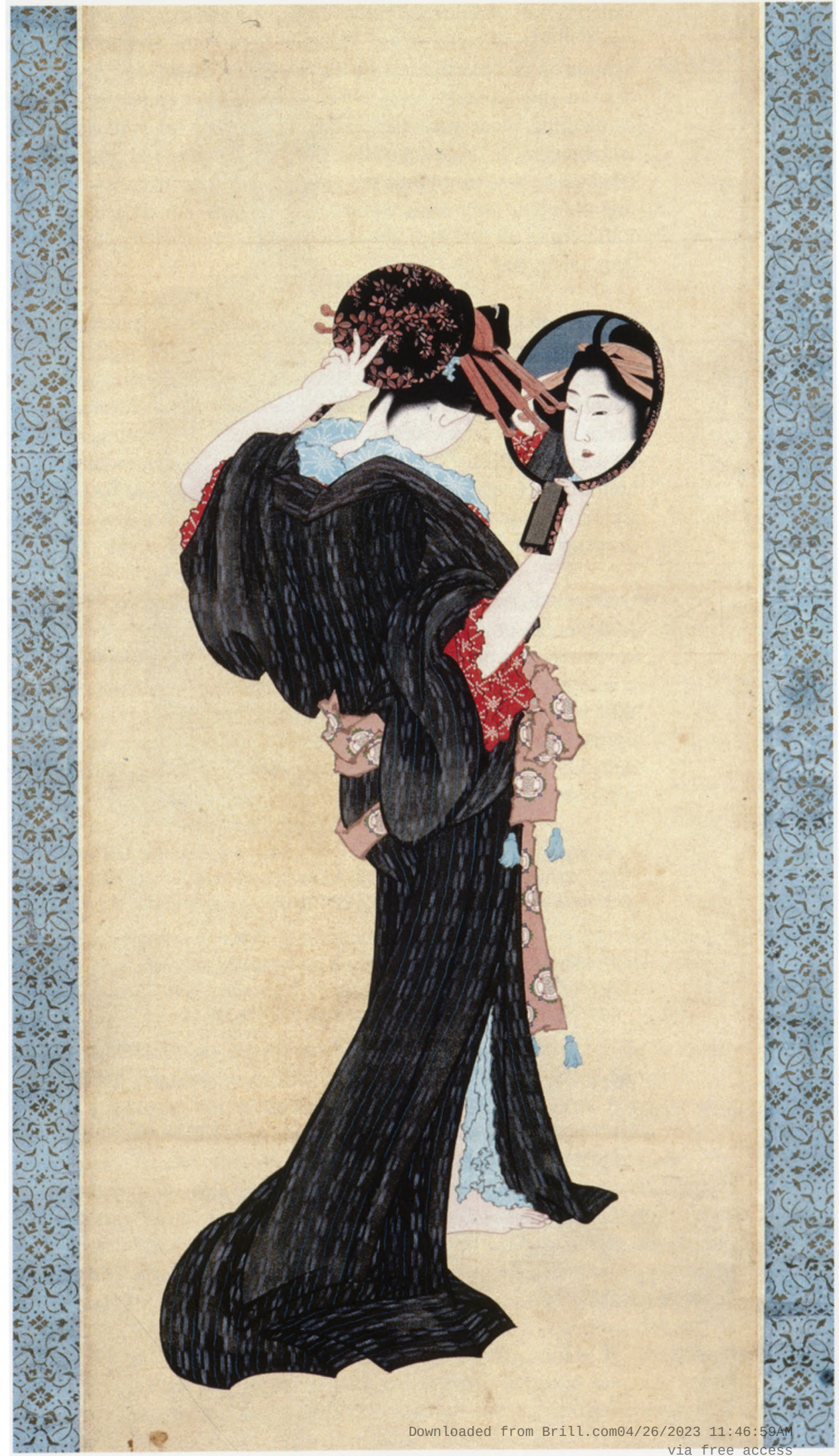

